\title{
POLA ASUH ORANGTUA DAN KECENDERUNGAN DELINKUENSI PADA REMAJA
}

\author{
Garvin \\ Program Studi Psikologi Universitas Bunda Mulia \\ ggoei@bundamulia.ac.id
}

\begin{abstract}
Adolescents undergo drastic changes in terms of physical, cognitive, emotional, and psychosexual aspects. Those changes result in unstable emotions within themselves. Accompanied with high level of curiosity as a process of searching for identity, this emotional instability causes adolescents to frequently engage in actions that do not comply with the rules and norms of the society, known as juvenile delinquency. This stud aims at discovering whether permissive, authoritative, and authoritarian parenting styles are related to juvenile delinquency tendency. The participants of this study are 151 students from $X$ school. This study can be considered as a quantitative research with correlational non-experimental design. Due to abnormal data distribution, Spearman correlation test was used to analyze the data. This study concluded that authoritarian and permissive parenting styles are not related to juvenile delinquency tendency $(p>0.05)$ whereas authoritative parenting style is significantly related to juvenile delinquency tendency $(p<0.05)$. Furthermore, the direction of the relationship between authoritative parenting style and juvenile delinquency tendency revealed negative correlation, which means the more authoritative the parenting style is, the lower the tendency will be.
\end{abstract}

Keywords: Juvenile delinquency, authoritative parenting style, authoritarian parenting style, permissive parenting style

\begin{abstract}
ABSTRAK
Remaja mengalami perubahan yang drastis baik dari segi fisik, kognitif, maupun psikoseksual sehingga menyebabkan emosi yang tidak stabil. Emosi yang tidak stabil ini, disertai dengan rasa keingintahuan yang besar sebagai proses pencarian identitas, membuat remaja tidak jarang terlibat dalam tindakan yang tidak sesuai dengan aturan maupun norma masyarakat atau yang dikenal sebagai delinkuensi remaja. Penelitian ini bertujuan untuk melihat apakah pola asuh permissive, authoritative, maupun authoritarian memiliki hubungan dengan kecenderungan delinkuensi remaja. Partisipan penelitian sebanyak 151 siswa sekolah X. Penelitian ini menggunakan metode kuantitatif non-eksperimental berjenis korelasional. Karena distribusi data tidak normal, pengujian yang digunakan adalah korelasi Spearman. Penelitian ini menyimpulkan bahwa pola asuh authoritarian dan permissive tidak berhubungan dengan kecenderungan delinkuensi remaja ( $\mathrm{p}>0.05$ ), sedangkan pola asuh authoritative berhubungan secara signifikan dengan kecenderungan delinkuensi remaja $(\mathrm{p}<0.05)$. Adapun arah hubungan pola asuh authoritative dan kecenderungan delinkuensi remaja adalah negatif, yang berarti semakin orangtua menerapkan pola asuh authoritative, maka kecenderungan delinkuens remaja akan semakin rendah.
\end{abstract}

Kata kunci:Delinkuensi remaja, pola asuh authoritative, pola asuh authoritarian, pola asuh permissive

\section{PENDAHULUAN \\ 1.1 Latar Belakang}

Remaja merupakan masa peralihan antara anak-anak menuju dewasa (Steinberg, 2011). Beberapa perubahan terjadi di masa remaja; baik secara fisik, kognitif, maupun psikososial (Papalia \& Feldman, 2012). Secara fisik dan biologis, remaja mengalami pubertas yang berdampak pada pertumbuhan fisik secara drastis pada remaja. Secara kognitif, remaja juga mengalami kemajuan yang pesat sehingga mampu melakukan 
berbagai pemikiran yang lebih logis daripada anak-anak, seperti berpikir deduktif atau berpikir hipotetis (Steinberg, 2011; Papalia \& Feldman, 2012). Secara psikososial, remaja mulai memasuki tahap yang disebut dengan identity $v s$ identity confusion (Erikson dalam Papalia \& Feldman, 2012).

Masa pencarian identitas ini biasanya diikuti dengan keinginan untuk mengeksplorasi banyak hal di lingkungannya guna mendapatkan nilai-nilai yang dapat diadopsi (Steinberg, 2011). Sayangnya, terkadang remaja bisa mengadopsi nilai-nilai yang tidak bermanfaat bagi dirinya. Di sisi lain, remaja juga mulai menyukai mencoba sesuatu, tanpa memedulikan hal tersebut akan bermanfaat atau tidak (Fatimah, 2006). Perasaan ingin mencoba dan nilai-nilai yang negatif terkadang diadposi oleh remaja sehingga mereka melakukan perbuatan yang tidak diharapkan oleh lingkungan yang seringkali disebut sebagai kenakalan remaja aau delinkuensi remaja. Hal ini ditambah lagi dengan kecerdasan emosi remaja akhir di Indonesia yang secara umum masih tergolong sedang (Aini \& Azhar, 2010), sehingga kemampuan remaja dalam mengontrol emosinya belum tergolong baik. Bila kondisi remaja akhir saja masih memiliki kecerdasan emosional yang tergolong sedang, maka masa remaja awal dan madya pun belum tentu lebih baik dari masa remaja akhir.

Di Indonesia, khususnya Jabodetabek, perilaku delinkuensi pada remaja sudah cukup memprihatinkan, khususnya tawuran remaja. Pada bulan Agustus 2016, Polsek Kembangan menangkap puluhan pelajar SMP yang kedapatan membawa senjata tajam untuk melakukan tawuran melawan sekolah lain (Panduwinata, 2016). Pada bulan Juni 2016, terjadi tawuran pelajar SMP di Bekasi yang menyebabkan tewasnya salah seorang remaja yang ikut terlibat dalam tawuran tersebut, akibat tertusuk benda tajam di bagian dada (Kusuma, 2016). Mei 2016 lalu, polisi mengamankan pelajar SMP 123 Kelapa Gading yang tertangkap membawa celurit, gir, dan benda tajam lainnya (Fajar, 2016). Menurut pengakuan
$\mathrm{NH}$, pelajar yang tertangkap tersebut, bendabenda tajam yang ia bawa akan ia gunakan untuk melakukan aksi tawuran melawan pelajar SMP 158 Jatinegara. Tidak hanya pelajar SMP, pelajar SMA dan SMK pun banyak terlibat dalam tindakan delinkuensi. Pada Agustus 2016 lalu, seorang pelajar tewas akibat terlibat tawuran antar pelajar SMKN 4 dan SMK PGRI 2 di Tangerang (Irawan, 2016). Demikian juga tawuran antar SMK di kawasan Jakarta Utara yang menyebabkan tewasnya seorang pelajar (Fajar, 2016). Baru-baru ini, di bulan Oktober 2016, seorang pelajar SMK Karawang tewas karena terlibat tawuran yang disebabkan oleh tindakan saling ejek (Masnurdiansyah, 2016). Contoh-contoh tersebut hanyalah beberapa tindakan delinkuensi remaja dalam bentuk tawuran yang terjadi pada tahun 2016 saja.

Tidak hanya tawuran, bentuk perilaku delinkuensi pada remaja di Indonesia, khususnya Jabodetabek, juga muncul dalam bentuk penyalahgunaan zat dan obat-obatan. Polsek Cempaka Putih menangkap seorang pelajar SMK yang merupakan pengguna narkoba berjenis sabu pada bulan Mei 2016 (Firmansyah, 2016). Pada bulan September 2016, Polres Bogor dan Bogor Kota juga menangkap pengedar dan pengguna narkoba yang berasal dari kalangan pelajar dan mahasiswa (Haryudi \& Purnama, 2016). Bahkan menurut Hidayat (dalam Tambun, 2016), setelah Badan Nasional Narkotika Provinsi DKI Jakarta melakukan pemeriksaan di 3 sekolah di Jakarta, ditemukan ada 82 siswa yang positif menggunakan narkoba. Data tersebut baru berdasarkan 3 sekolah di Jakarta saja. Datadata tersebut baru menggambarkan sebagian delinkuensi remaja dalam hal penyalahgunaan obat-obatan di Jakarta saja. Belum lagi di kota-kota lainnya di Indonesia. Perilaku delinkuensi pun tidak hanya terkait tawuran dan narkotika, tapi juga mencakup perusakan fasilitas umum, tindakan membolos, bully-ing, dan sebagainya. Hal ini tentu menjadi sesuatu yang perlu mendapatkan perhatian bagi berbagai pihak.

Menurut Steinberg (2011), frekuensi kriminalitas meningkat antara masa-masa 
pra-remaja dan remaja, kemudian memuncak ketika masa sekolah menengah atas, dan menurun ketika memasuki dewasa muda. Fatimah (2006) menyatakan bahwa remaja sering memberontak yang merupakan ekspresi perubahan dari anakanak menjadi remaja.

Penyebab dari perilaku kenakalan remaja atau delinkuensi ini sudah berkalikali menjadi bahan penelitian. Kriminalitas dan kenakalan remaja dimediasi oleh keterlibatan orang tua dan jenis kelamin; yaitu perempuan lebih berpotensi daripada laki-laki (Walters, 2013). Ryan, Marshall, Herz, dan Hernandez (2008) menemukan bahwa kenakalan atau perilaku delinkuensi pada remaja dipengaruhi oleh pengalaman kekerasan fisik dan pengabaian dari keluarga. Riset yang dilakukan sebelumnya oleh Suhardja (2008) menemukan bahwa terdapat hubungan yang negatif antara pola asuh authoritative dan kecenderungan delinkuensi pada remaja.

Beberapa hasil riset yang sudah diuraikan pada paragraf sebelumnya menunjukkan hasil yang seragam, yaitu delinkuensi pada remaja berkaitan dengan keluarga. Pada masa remaja, keluarga merupakan salah satu lingkungan yang paling berpengaruh terhadap perkembangan remaja, terutama orang tua. Laursen \& Collins (2009) berpendapat bahwa orang tua memiliki pengaruh yang besar terhadap remaja, terutama pengaruh yang berkait dengan isu-isu remaja di masa depan seperti sekolah dan karir. Lebih jauh lagi, hubungan dengan orang tua merupakan hubungan yang paling berpengaruh terhadap remaja dan paling banyak memengaruhi pembentukan pengambilan keputusan yang penting dalam kehidupan remaja (Laursen \& Collins, 2009).

Berdasarkan uraian-uraian di atas, dapat diasumsikan bahwa orangtua terutama dalam kaitan pola asuh, memiliki peran terhadap delinkuensi pada usia remaja. Pola asuh merupakan cara orangtua untuk berinteraksi dengan anaknya secara umum (Bjorkblund \& Blasi, 2012). Berdasarkan penelitian terakhir, ada empat macam pola asuh yang diterapkan oleh orangtua terhadap anaknya, yakni authoritative, authoritarian, permissive, dan uninvolved/neglectful parenting (Baumrind dalam Bjorkblund \& Blasi, 2012). Keempat pola pengasuhan tersebut dibedakan berdasarkan dua aspek, yakni kehangatan dan kontrol. Pola asuh authoritative, misalnya, memiliki kehangatan yang tinggi disertai kontrol terhadap remaja yang tinggi pula. Pola asuh authoritarian memiliki kehangatan yang rendah, namun kontrol orangtua tetap tinggi. Pada pola asuh permissive, kehangatan dari orangtua tergolong tinggi dengan kontrol yang rendah terhadap remaja. Sedangkan pola asuh uninvolved atau neglectful memiliki kehangatan serta kontrol yang rendah.

Bjorkblund dan Blasi (2012) menyatakan bahwa keempat pola pengasuhan tersebut berasosiasi dengan karakteristik yang berbeda-beda pada anak maupun remaja. Misalnya, sebuah studi yang dilakukan oleh Garcia dan Gracia (2009) menemukan bahwa remaja yang diasuh dengan permissive parenting dan authoritative parenting memiliki skor yang lebih tinggi pada self-esteem dan penyesuaian diri, serta memiliki skor yang lebih rendah dalam masalah perilaku.

Buehler (dalam Papalia dan Martorell, 2014) menyatakan bahwa perilaku bermasalah pada remaja dipengaruhi oleh beberapa faktor, yang salah satunya adalah relasi remaja dengan orangtua. Remaja umumnya memiliki keinginan yang besar untuk memeroleh otonomi dan ingin mendapatkan pengawasan yang kurang dari orangtua (Schulenberg dan Zarrett dalam Papalia dan Martorell, 2014). Bila pola pengasuhan dari orangtua terhadap remaja melibatkan kehangatan dan kontrol, maka usaha orangtua untuk mengendalikan remaja bisa mengalami benturan dengan keinginan remaja untuk berotonomi. Di sisi lain, beberapa pola pengasuhan juga menawarkan kehangatan kepada remaja, sehingga orangtua bisa mengomunikasikan maksud dan tujuannya dalam mengendalikan perilaku remaja dengan baik. Peneliti berhipotesis bahwa variasi dalam kehangatan dan kontrol dalam pola asuh, yang membentuk empat macam pola asuh, 
memberikan dampak yang berbeda terhadap kecenderungan perilaku delinkuensi pada remaja. Berdasarkan uraian-uraian di atas, peneliti bermaksud untuk melakukan penelitian mengenai pola asuh orangtua dan kecenderungan delinkuensi pada remaja.

\subsection{Tujuan Penelitian}

Penelitian ini bertujuan untuk menguji hubungan antara ketiga macam pola asuh yakni (1) authoritarian, (2) authoritative, dan (3) permissive dengan kecenderungan delinkuensi pada remaja.

\section{TINJAUAN PUSTAKA \\ 2.1 Delinkuensi Remaja}

Stein \& Book (2006) menyatakan bahwa Delinkuensi remaja dapat didefinisikan sebagai semua tingkah laku remaja yang menyimpang dari ketentuan yang berlaku dalam masyarakat - yakni norma agama, etika, peraturan sekolah, keluarga, dan lain-lain - dan berkaitan dengan norma-norma hukum pidana (Sarwono, 2006). Gold dan Petronio (dalam Sarwono, 2006) mendefinisikan delinkuensi remaja sebagaitindakan remaja yang sengaja melanggar hukum dan bila diketahui oleh pihak yang berwajib maka pelanggarnya dapat dikenai hukuman. Berdasarkan kedua definisi di atas, dapat disimpulkan bahwa perilaku delinkuensi remaja dapat didefinisikan sebagai perilaku kenakalan remaja yang melanggar hukum.

Jensen (dalam Sarwono, 2006) membagi perilaku delinkuensi remaja menjadi empat jenis, yaitu (1) kenakalan yang menimbulkan korban fisik pada orang lain, (2) kenakalan yang menimbulkan korban materi, (3) kenakalan sosial yang tidak menimbulkan korban di pihak lain, dan (4) kenakalan yang melawan status.

Perilaku delinkuensi yang pertama, yaitu kenakalan yang menimbulkan korban fisik pada orang lain, contohnya adalah perkelahian, perkosaan, perampokan, pembunuhan, dan lain-lain (Sarwono, 2006). Perilaku tersebut sengaja dilakukan oleh remaja dan menyebabkan rasa sakit, luka, atau merusak kesehatan pihak lain.

Perilaku delinkuensi remaja yang kedua adalah kenakalan yang menimbulkan korban materi; contohnya adalah perusakan, pencurian, pencopetan, pemerasan, dan lainlain (Sarwono, 2006). Perilaku ini dilakukan secara sengaja oleh remaja yang menyebabkan pengalihan hak milik materi tanpa seizing dari pemilik yang pertama. Selain itu, perilaku delinkuensi kedua ini juga mencakup perusakan fasilitas umum maupun barang milik orang lain.

Perilaku delinkuensi yang ketiga adalah kenakalan sosial yang tidak menimbulkan korban di pihak lain; contohnya adalah pelacuran, zat, dan lainlain (Sarwono, 2006). Perilaku ini tidak merugikan orang lain, tetapi merugikan sang pelaku, yaitu remaja itu sendiri. Perlu diperhatikan bahwa meskipun di Indonesia melakukan hubungan seks di luar nikah dapat dianggap sebagai pelanggaran hukum, namun di negara lain hal ini masih dapat diterima dan tidak dianggap sebagai delinkuensi.

Perilaku delinkuensi yang keempat, kenakalan yang melawan status, contohnya adalah membolos, minggat dari rumah, membantah perintah orang tua, dan sebagainya (Sarwono, 2006). Meskipun tidak melanggar hukum pidana, namun pelaku sudah melanggar status-status dalam lingkungan mereka. Jika dibiarkan, hal ini dapat berdampak remaja dapat melakukan hal ini kepada atasannya kelak atau kepada petugas hukum (Sarwono, 2006).

Graham (dalam Sarwono, 2006) membagi faktor-faktor penyebab perilaku delinkuensi remaja menjadi 2 golongan besar, yaitu (1) faktor lingkungan, dan (2) faktor pribadi.

Faktor lingkungan merupakan faktor penyebab delinkuensi remaja yang berasal dari luar diri remaja, seperti kemiskinan, gangguan lingkungan, migrasi, faktor sekolah, keluarga, atau gangguan dalam pengasuhan orang tua (Sarwono, 2006). Gangguan pengasuhan misalnya adalah hubungan antaranggota keluarga (khususnya orang tua dan anak) yang tidak harmonis atau adanya ketidaklengkapan dalam anggota keluarga. Hasil studi dari Wijaya, Widiastuti, dan Nisfiannor (2010) menunjukkan bahwa pendidikan agama berkorelasi secara negatif dengan perilaku delinkuensi remaja. 
Faktor pribadi merupakan faktor penyebab delinkuensi remaja yang berasal dari dalam diri remaja, yaitu faktor temperamen, cacat tubuh, atau ketidakmampuan dalam menyesuaikan diri (Sarwono, 2006). Meskipun berasal dari dalam diri, namun remaja tetap berada di bawah naungan orang tua; sehingga faktor dari dalam diri tersebut seharusnya dapat diarahkan oleh orang tua.

\subsection{Pola Asuh}

Pola asuh merupakan cara orangtua dalam berinteraksi dengan anaknya (Bjorkblund \& Blasi, 2012). Secara umum, para ahli psikologi menyepakati bahwa pola asuh memiliki dua dimensi, yakni: (a) tingkat kehangatan orangtua terhadap anak, dan (b) tingkat kendali dari orangtua terhadap perilaku anak (Bjorkblund \& Blasi, 2012). Kehangatan orangtua tercermin dari anak yang merasa dicintai dan diperhatikan oleh orangtua mereka, serta adanya keterlibatan orangtua ke dalam kehidupan; sedangkan kontrol merujuk pada usaha orangtua untuk mendorong perilaku yang lebih dewasa pada anak dengan beragam cara. Dari kedua dimensi tersebut, Baumrind (dalam Bjorkblund dan Blasi, 2012) menemukan bahwa ada empat macam pola asuh yang diterapkan oleh orangtua, yakni: (a) authoritative parenting, (b) authoritarian parenting, (c) permissive parenting, dan (d) uninvolved atau neglectful parenting.

\subsubsection{Authoritative Parenting}

Bjorkblund dan Blasi (2012) mendefinisikan authoritative parenting sebagai pola pengasuhan di mana orangtua menentukan standar yang jelas dan melasanakan aturan dengan cara yang hangat dan disertai dengan penjelasan. Pada pola pengasuhan ini, orangtua mampu memberikan aturan-aturan yang jelas kepada remaja serta menjelaskan alasan aturan tersebut ditetapkan. Orangtua juga melaksanakan aturan dengan hangat dan terbuka, sehingga seringkali diskusi antara anak dan orangtua pun terbentuk melalui pola pengasuhan ini. Sifat dari pola asuh authoritative adalah memiliki kehangatan yang tinggi dengan kendali yang tinggi terhadap anak maupun remaja.

\subsubsection{Authoriatrian Parenting}

Authoriatrian parenting didefinisikan sebagai pola pengasuhan di mana orangtua mengharapkan kepatuhan yang mutlak dan seringkali melaksanakan peraturan dengan hukuman fisik maupun penarikan kasih sayang (Bjorkblund dan Blasi, 2012). Orangtua dengan pola pengasuhan authoritatian menekankan aturan yang kaku, sehingga remaja harus mematuhinya dan disertai dengan hukuman bila terjadi pelanggaran. Sifat dari pola asuh authoritarian adalah memiliki kehangatan yang rendah dengan kendali yang tinggi terhadap anak maupun remaja.

\subsubsection{Permissive Parenting}

Bjorkblund dan Blasi (2012) mendefinisikan permissive parenting dengan gaya pengasuhan di mana orangtua bersikap hangat dan bersahabat, namun cenderung sedikit mengendalikan perilaku remaja. Orangtua yang menerapkan permissive parenting cenderung tidak menuntut maupun berusaha untuk mengendalikan remaja, serta sangat sedikit melibatkan hukuman. Sifat dari pola asuh permissive adalah memiliki kehangatan yang tinggi namun pengendalian yang redah terhadap anak atau remaja.

\subsubsection{Uninvolved Parenting}

Uninvolved atau neglectful parenting merupakan pola asuh di mana orangtua tidak terlibat dengan remaja, sehingga sifatnya dingin, acuh tak acuh, dan sangat sedikit menuntut (Bjorkblund dan Blasi, 2012). Sifat dari pola asuh uninvolved adalah memiliki kehangatan yang rendah disertai dengan pengendalian yang rendah terhadap anak maupun remaja.

\section{METODE PENELITIAN}

Penelitian ini termasuk dalam jenis penelitian kuantitatif non-eksperimental, yakni peneliti tidak melakukan manipulasi atau menciptakan variabel-variabel yang akan diukur. Adapun penelitian ini bersifat korelasional karena mencari hubungan antara dua variabel. Tujuan dari penelitian ini adalah: (a) mencari hubungan antara pola asuhauthoritative terhadap kecenderungan remaja, (b) mencari hubungan antara pola asuhauthoritarian terhadap kecenderungan 
remaja dan (c) mencari hubungan antara pola asuhpermissive terhadap kecenderungan remaja.

Penelitian ini melibatkan 151 orang partisipan yang merupakan siswa dari Sekolah X di Jakarta Utara. Alasan peneliti mengambil data di Sekolah X adalah karena siswa di Sekolah X hampir setiap tahun terlibat dalam kegiatan tawuran minimal satu kali dan laporan dari guru bahwa siswasiswa di Sekolah X cenderung liar serta sulit untuk diatur. Teknik pensampelan yang digunakan adalah incidental sampling, yang berarti peneliti mengambil data terhadap semua siswa yang hadir ketika peneliti datang ke Sekolah X.

Peneliti menggunakan alat ukur kecenderungan delinkuensi remaja yang disusun berdasarkan jenis-jenis delinkuensi yang dikonsepkan oleh Jensen (dalam Sarwono, 2006). Alat ukur kecenderungan delinkuensi terdiri dari 36 butir dengan masing-masing butirnya memiliki lima pilihan respon, dari sangat tidak setuju hingga sangat setuju. Contoh butir dalam alat ukur kecenderungan delinkuensi adalah, "Saya mengambil barang orang lain dengan paksa saat tidak diberikan pada saya" untuk butir favorable dan "Saya akan berbicara baik-baik dengan anggota keluarga jika saya menghadapi masalah" untuk butir unfavorable. Alat ukur ini berbentuk kuesioner dan diisi oleh partisipan. Nilai Cronbach's Alpha dari alat ukur kecenderungan delinkuensi adalah 0.941 sehingga peneliti menyimpulkan bahwa alat ukur reliabel.

Sedangkan untuk mengukur pola asuh orangtua, peneliti menggunakan Parental Authority Questionnaire (untuk selanjutnya akan ditulis sebagai "PAQ")yang diadaptasi ke dalam Bahasa Indonesia. PAQ mengukur tiga pola asuh orangtua, yakni pola asuh authoritative, authoritarian, dan permissive. PAQ terdiri dari 30 butir untuk menilai ayah dan 30 butir untuk menilai ibu. Baik untuk ayah dan ibu memiliki butir yang sama, kecuali hanya berbeda pada kata "ayah" dan "ibu". Contoh butir dari alat ukur Parental Authority Questionnaire adalah, "ketika membuat aturan di dalam keluarga, ayah/ibu saya mengajak saya untuk mendiskusikan alasan di balik aturan tersebut," untuk butir pola asuh authoritative, sedangkan contoh butir pola asuh authoritarian adalah, "ayah/ibu saya memberitahukan perilaku yang ia harapkan terhadap saya, dan jika saya tidak memenuhi harapannya maka ia akan menghukum saya." Adapun contoh butir untuk pola asuh permissive adalah, "ayah/ibu saya tidak mengarahkan perilaku, kegiatan, maupun keinginan anak-anaknya di dalam keluarga." Sama dengan alat ukur kecenderungan delinkuensi, PAQ terdiri dari 5 macam respons dari "sangat tidak sesuai" hingga "sangat sesuai". PAQ juga diisi oleh partisipan, sebagai bentuk penilaian atau persepsi dari sampel terhadap pola asuh orangtuanya. Nilai Cronbach's Alpha dari PAQ adaptasi Bahasa Indonesia adalah 0.887 sehingga peneliti menyimpulkan bahwa alat ukur reliabel.

Pengujian yang digunakan dalam penelitian ini adalah uji korelasi. Bila data berdistribusi normal, uji korelasi yang digunakan adalah Pearson; namun bila data tidak tersebar dengan normal, maka uji korelasi yang digunakan adalah Spearman. Dalam proses pengolahan data dan pengujian, peneliti menggunakan software SPSS versi 19.

\section{HASIL DAN PEMBAHASAN}

Hasil pengolahan data menunjukkan bahwa $24.50 \%$ atau 37 orang partisipan memiliki kecenderungan delinkuensi yang tergolong rendah, $50.33 \%$ atau 76 orang partisipan memiliki kecenderungan delinkuensi yang tergolong sedang, dan $25.17 \%$ atau 38 orang partisipan memiliki kecenderungan delinkuensi yang tergolong tinggi. Penggolongan ini menggunakan persentil, yakni partisipan yang memiliki skor kecenderungan delinkuensi di bawah skor pada persentil ke-25 dikategorikan sebagai rendah, sedangkan partisipan dengan skor di atas persentil ke-75 dikategorikan sebagai tinggi. Adapun partisipan yang memiliki skor di antara persentil ke-25 dan ke-75 digolongkan dalam kategori sedang. 
Tabel 1. Gambaran Kecenderungan Delinkuensi Subjek

\begin{tabular}{lcc}
\hline Kategori & Frekuensi & Persentase \\
\hline Rendah & 37 orang & $24.50 \%$ \\
Sedang & 76 orang & $50.33 \%$ \\
Tinggi & 38 orang & $25.17 \%$ \\
\hline Total & $\mathbf{1 5 1}$ orang & $\mathbf{1 0 0 \%}$ \\
\hline
\end{tabular}

Sedangkan hasil pengolahan data pola asuh orangtua menunjukkan bahwa sebagian besar partisipan menilai orangtua mereka menerapkan pola asuh authoritative, dengan frekuensi sebanyak 85 orang dan persentase sebesar $56.30 \%$. Disusul oleh pola asuh authoritarian dengan frekuensi 53 orang dan persentase $35.10 \%$, dan pola asuh permissive dengan frekuensi sebesar 13 orang dan persentase sebesar $8.60 \%$. Adapun penggolongan pola asuh ini dilakukan dengan menjumlahkan skor dari masing-masing dimensi pola asuh permissive, authoritative, dan authoritarian; kemudian skor yang tertinggi dianggap sebagai pola asuh yang paling sering digunakan oleh orangtua terhadap remaja.

Tabel 2. Gambaran Pola Asuh Orangtua dari Subjek Penelitian

\begin{tabular}{lcc}
\hline Kategori & Frekuensi & Persentase \\
\hline Permissive & 13 orang & $8.60 \%$ \\
Authoritarian & 53 orang & $35.10 \%$ \\
Authoritative & 85 orang & $56.30 \%$ \\
\hline Total & 151 orang & $\mathbf{1 0 0 \%}$ \\
\hline
\end{tabular}

Uji normalitas data dilakukan dengan menggunakan uji KolmogorovSmirnov. Hasil dari uji KolmogorovSmirnov menunjukkan nilai signifikansi variabel pola asuh adalah $p=0.689>0.05$ sehingga data dianggap berdistribusi normal, namun nilai signifikansi pada variabel kecenderungan delinkuensi adalah $\mathrm{p}=0.014$ $<0.05$ sehingga data dianggap tidak berdistribusi normal. Oleh karena itu, pengujian yang digunakan di dalam penelitian ini adalah uji statistik nonparametrik.

Karena penyebaran data tidak normal, maka peneliti menggunakan uji korelasi Spearman untuk melihat hubungan antara ketiga variasi pola asuh terhadap kecenderungan delinkuensi remaja. Hasil uji korelasi Spearman untuk pola asuh authoritarian terhadap kecenderungan delinkuensi menunjukkan $\mathrm{p}=0.151>0.05$ sehingga peneliti menyimpulkan tidak ada hubungan yang signifikan antara keduanya. Selanjutnya, hasil uji korelasi Spearman untuk pola asuh authoritative terhadap kecenderungan delinkuensi menghasilkan $\mathrm{p}$ $=0.000<0.05$, dengan koefisien korelasi sebesar -0.361, yang berarti terdapat hubungan yang signifikan antara pola asuh authoritative dengan kecenderungan delinkuensi, dan hubungan tersebut bersifat negatif. Hasil uji korelasi selanjutnya adalah pola asuh permissive terhadap kecenderungan delinkuensi, yang menghasilkan $\mathrm{p}=0.226>0.05$ yang berarti tidak ada hubungan yang signifikan antara keduanya.

Tabel 3. Signifikansi Uji Korelasi Spearman antara Pola Asuh terhadap Kecenderungan Delinkuensi

\begin{tabular}{lcl}
\hline Pola Asuh & $\begin{array}{c}\text { Signifikansi } \\
(\mathbf{p})\end{array}$ & Simpulan \\
\hline Authoritarian & 0.151 & $\begin{array}{l}\text { Tidak ada } \\
\text { hubungan }\end{array}$ \\
Authoritative & 0.000 & $\begin{array}{l}\text { Ada } \\
\text { hubungan }\end{array}$ \\
Permissive & 0.226 & $\begin{array}{l}\text { Tidak ada } \\
\text { hubungan }\end{array}$ \\
\hline
\end{tabular}

Keterangan: signifikansi pada tingkat 0.05

\section{SIMPULAN DAN SARAN}

Berdasarkan hasil uji korelasi Spearman pada pola asuh authoritarian, authoritative, dan permissive terhadap kecenderungan delinkuensi remaja, ditemukan bahwa pola asuh authoritarian dan permissive tidak berkorelasi secara signifikan dengan kecenderungan delinkuensi. Hanya pola asuh authoritative yang berkorelasi secara signifikan dengan kecenderungan delinkuensi remaja dan arah korelasi tersebut bersifat negatif. Hal ini berarti, semakin remaja mempersepsikan bahwa orangtuanya mengasuh dengan gaya authoritative, maka kecenderungan 
delinkuensinya menurun, demikian juga dengan sebaliknya.

Penelitian yang dilakukan oleh Rahmania \& Suminar (2012) menemukan bahwa persepsi terhadap kontrol orangtua memiliki korelasi yang negatif dengan kecenderungan delinkuensi remaja. Di sisi lain, Hoeve et al. (2009) juga menemukan bahwa pengawasan dari orangtua terhadap anak memiliki hubungan yang negatif dengan delinkuensi remaja. Hal ini selaras dengan temuan dalam penelitian ini bahwa pola asuh authoritative juga memiliki korelasi yang negatif dengan kecenderungan delinkuensi. Seperti yang diungkapkan oleh Bjorkblund dan Blasi (2012) bahwa pola asuh authoritative melibatkan kontrol dan kehangatan dari orangtua, maka kedua hasil temuan yang konsisten ini menekankan perlunya kontrol dari orangtua terhadap perilaku anak untuk menekan kecenderungan delinkuensi pada anak. Namun, dalam penelitian ini juga ditemukan bahwa pola asuh authoritarian tidak memiliki korelasi yang signifikan dengan kecenderungan delinkuensi remaja. Pola asuh authoritarian hanya melibatkan kontrol tanpa mengikutsertakan kehangatan (Bjorkblund \& Blasi, 2012), tercermin dalam perilaku orangtua yang hanya menetapkan aturan maupun larangan kepada anaknya tanpa menjelaskan makna larangan tersebut atau mengajak anak untuk mendiskusikannya.

Dalam penelitian selanjutnya, perlu dicari tahu peran kehangatan orangtua serta interaksinya dengan kontrol orangtua terhadap kecenderungan delinkuensi pada remaja.

Saran bagi orangtua, diharapkan agar lebih menerapkan pola asuh authoritative agar bisa menekan kecenderungan delinkuensi pada remaja. Orangtua menetapkan standar atau aturan yang perlu dipatuhi oleh remaja, tetapi orangtua juga menjelaskan makna ataupun tujuan di balik aturan tersebut dengan cara yang hangat sehingga remaja dapat memahaminya dengan jelas. Selain itu, orangtua juga tetap memberikan kesempatan kepada remaja untuk berdialog secara verbal dengan orangtua mengenai hal-hal yang berkaitan dengan remaja.

\section{DAFTAR PUSTAKA}

Aini F.Q., \& Azhar, S.R.R.P. (2010). Kecerdasan emosi dan agresitivitas pada remaja akhir. Jurnal Ilmiah Psikologi, 4(1), 14-24.

Berk, L. (2012). Infants, children, and adolescents ( $7^{\text {th }}$ ed.). Boston: Pearson.

Bjorkblund, D.F., \& Blasi, C.H. (2012). Child and adolescent development: An integrated approach. NY: McGraw-Hill.

Fajar, T. (2016, 8 September). Tawuran dua SMK di Jakarta Utara menewaskan satu pelajar. Okezone. Diakses dari http://news.okezone.com/read/2016/ 09/08/338/1485018/tawuran-dua-smkdi-jakarta-utara-menewaskan-satupelajar

Fatimah, E. (2006). Psikologi perkembangan: Perkembangan peserta didik. Bandung: Pustaka Setia.

Firmansyah, T. (2016, 20 Mei). Terlibat transaksi narkoba, pelajar ditangkap di parkiran. Republika. Diakses dari http://nasional.republika.co.id/berita /nasional/jabodetabeknasional/16/05/20/o7gg4y377-terlibattransaksi-narkoba-pelajar-ditangkapdi-parkiran.

Garcia, F., \& Gracia, E. (2009). Is always authoritative the optimum parenting style? Evidence from Spanish families. Adolescence, 44(173), 31131.

Haryudi, \& Purnama, R.R. (2016, 2 September). Telibat narkoba, mahasiswa dan pelajar ditangkap. Koran Sindo. Diakses dari http://www.koran-sindo.com/news. php? $=0 \& n=36 \&$ date $=2016-09-02$. 
Hoeve, M., Dubas, J.S., Eichelsheim, V.I., Laan, P.H., Smeenk, W., \& Gerris, J.R.M. (2009). The relationship between parenting and delinquency: a meta-analysis. Journal of Abnormal Child Psychology, 37(6), 749-775.

Irawan, D. (2016, 20 Agustus). Tawuran, siswa SMKN 4 Tangerang tewas ditusuk. Okezone. Diakses dari http://news.okezone.com/read/2016/0 8/ 20/338/1468970/tawuran-siswasmkn-4-tangerang-tewas-ditusuk.

Kusuma, E.F. (2016, 19 Mei). Polisi temukan celurit dan gir di tas pelajar SMP yang akan tawuran. Detik News. Diakses dari https://news.detik.com/berita/3214144 /polisi-temukan-celurit-dan-gir-di-taspelajar-smp-yang-akan-tawuran.

Laursen, B., \& Collins, W.A. (2009). Parentchild relationships during adolescence. Dalam R.M. Lerner \& L. Steinberg (Eds.), Handbook of Adolescent Psychology Vol. 2. NJ: Wiley \& Sons.

Masnurdiansyah. (2016, 6 Oktober). Saling ejek, pelajar SMK di Karawang terlibat tawuran, satu orang tewas. Detik News. Diakses dari http://news.detik.com/berita/d3314413/saling-ejek-pelajar-smk-dikarawang-terlibat-tawuran-satuorang-tewas

Panduwinata, A. (2016, 29 Agustus). Ngeri, pelajar SMP urunan beli sajam dan gir untuk tawuran. Warta Kota. Diakses dari http://wartakota. tribunnews.com/2016/08/29/ngeripelajar-smp-urunan-beli-sajam-dangir-untuk-tawuran

Papalia, D.E., \& Feldman, R.D. (2012). Experience human development $\left(12^{\text {th }}\right.$ ed.). NY: McGraw-Hill.
Papalia, D.E., \& Martorell, G. (2014). Experience human development $\left(13^{\text {th }}\right.$ ed.). NY: McGraw-Hill.

Rahmania, A.M., \& Suminar, D.R. (2012). Hubungan antara persepsi terhadap kontrol orangtua dengan kecenderungan perilaku delinkuensi pada remaja yang pernah terlibat tawuran. Jurnal Psikologi Pendidikan dan Perkembangan, 1(3), 1-7.

Ryan, J.P., Marshall, J.M., Herz, D., Hernandez, P.M. (2008). Juvenile delinquency in child welfare: Investigating group home effects. Children and Youth Services Review, 30, 1088-1099.

Sarwono, S.W. (2006). Psikologi remaja. Jakarta: Rajawali Perkasa.

Smetana, J.G., Metzger, A., Gettman, D.C., \& Campione-Barr, N. (2006). Disclosure and secrecy in adolescentparent relationships. Child Development, 77, 201-217. Steinberg, L. (2011). Adolescence ( $9^{\text {th }}$ ed.). NY: McGraw-Hill.

Suhardja, N.A. (2008). Kecenderungan perilaku delinkuensi pada remaja ditinjau dari pola asuh authoritative

Tambun, L.T. (2016, 29 Februari). 82 siswa SMA di Jakarta positif terkena orang tua. Skripsi, Universitas Katolik Soegijapranata, Semarang.

Tarigan, K.S. (2016, 2 Juni). Siswa SMP di Tambun tewas saat tawuran, polisi kejar pelaku. Detik News. Diakses dari

http://news.detik.com/berita/3224340/ siswa-smp-di-tambun-tewas-saattawuran-polisi-kejar-pelaku-narkoba. Berita Satu. Diakses dari http://www.beritasatu.com/ aktualitas/352007-82-siswa-sma-dijakarta-positif-narkoba.html.

Walters, G.D. (2013). Delinquency, parental involvement, early adult criminality, 
and sex: Evidence of moderated mediation. Journal of Adolescence, 26, 777-795.
Wijaya, E., Widiastuti, N., \& Nisfianoor, M. Hubungan pendidikan nilai agama dengan perilaku delinkuensi pada remaja madya di sekolah menengah atas. Provitae, 4(1), 13-25. 